\title{
Adaptive management in crop pest control in the face of climate variability: an agent-based modeling approach
}

\author{
François Rebaudo $^{1,2}$ and Olivier Dangles ${ }^{3,4}$
}

\begin{abstract}
Climate changes are occurring rapidly at both regional and global scales. Farmers are faced with the challenge of developing new agricultural practices to help them to cope with unpredictable changes in environmental, social, and economic conditions. Under these conditions, adaptive management requires a farmer to learn by monitoring provisional strategies and changing conditions, and then incrementally adjust management practices in light of new information. Exploring adaptive management will increase our understanding of the underlying processes that link farmer societies with their environment across space and time, while accounting for the impacts of an unpredictable climate. Here, we assessed the impacts of temperature and crop price, as surrogates for climate and economic changes, on farmers' adaptive management in crop pest control using an agent-based modeling approach. Our model simulated an artificial society of farmers that relied on field data obtained in the Ecuadorian Andes. Farmers were represented as heterogeneous autonomous agents who interact with and influence each other, and who are capable of adapting to changing environmental conditions. The results of our simulation suggest that variable temperatures led to less effective pest control strategies than those used under stable temperatures. Moreover, farmers used information gained through their own past experience or through interactions with other farmers to initiate an adaptive management approach. At a broader scale, this study generates more than an increased understanding of adaptive management; it highlights how people depend on one another to manage common problems.
\end{abstract}

Key Words: adaptive management; agent-based model; agro-ecosystems; farmers; pest

\section{INTRODUCTION}

Rapid and unpredictable change in climate at both regional and global scales is forcing agro-ecosystem stakeholders to develop new management practices (Perez et al. 2010). Conventional management practices have typically assumed that environmental and socioeconomic contexts will be predictable and roughly the same over long periods (Darnhoffer et al. 2010). Existing management practices will work well under this assumption (Shea et al. 2002). However, under conditions where social, economic, and ecological factors change rapidly or are unpredictable, steadystate management is no longer adequate (Susskind et al. 2012). Farmers must cope with sources of uncertainty to keep their farm sustainable and to maintain food security (Darnhoffer et al. 2010).

Adaptive management (AM) is "a systematic process for continually improving management policies and practices by learning from the outcomes of previously employed policies and practices" (MEA 2005). AM provides a way to adjust to change and uncertainty. Under AM, farmers learn by monitoring provisional strategies and changing conditions, and then make incremental adjustments to their management practices in response to what they have learned (Susskind et al. 2012). The concept of AM emerged by the late 1970 s as a way to improve natural resource management (Holling 1978). However, it is only relatively recently that $\mathrm{AM}$ has been applied to crop protection issues (Lewis et al. 1997, Shea et al. 2002).

Shea et al. (2002), in their seminal paper, convincingly state that $\mathrm{AM}$ is one of the best ways to control pests in the face of uncertainty. Most small-scale farmers do learn from the results of their own previous attempts at pest control. But they generally lack a framework for learning about the overall managed system, which they need to do to improve pest control at broad spatial and temporal scales. Although traditional farming communities are generally very resilient (Perez et al. 2010), unprecedented climatic and economic changes may push them beyond their range of adaptability. AM may provide useful new ways for them to adjust to change and uncertainty.

Agro-ecosystems are social-ecological systems in which humans play a key role in managing the landscape and affecting its spatiotemporal dynamics (Cabell and Oelofse 2012, Rounsevell et al. 2012). Research on AM in pest control must consider the intricate interactions between climatic (e.g., temperature), ecological (e.g., pest population dynamics), and socioeconomic systems.

Agent-based models (ABMs) provide an ideal methodological framework to represent coupled systems (Liu et al. 2007) and to integrate a dimension that represents farmers' decision making, which is central to AM (An 2012). In ABM, agents are heterogeneous and autonomous entities that interact with one another, which is suitable to explicitly represent the complexity of decision making (Watkins et al. 2013). Thus, ABMs make it possible to formalize and test hypotheses about the conditions under which complex patterns in management practices can emerge from a set of observed behavior-response functions (Zellner 2008, Rounsevell et al. 2012). ABMs have been applied to a variety of situations over the last 20 to 30 years, such as systems affected by land use and changes in land cover (e.g., Parker et al. 2003, Matthews et al. 2007) and resource management and conservation (e.g., Boone et al. 2011, Parrott et al. 2012, Watkins et al. 2013). Although a few studies have focused on agricultural systems (e.g., Berger 2001, Happe et al. 2006,

${ }^{1}$ UMR EGCE IRD-247 CNRS-UPSud-9191, ${ }^{2}$ Instituto de Ecología, Universidad Mayor de San Andres, ${ }^{3}$ Institut de Recherche pour le Développement, Laboratoire Evolution, Génomes, Comportement et Ecologie (UMR IRD, CNRS, Université Paris Sud), Université Paris-Saclay, Campus CNRS, 1 Avenue de la Terrasse, 91198 Gif-sur-Yvette Cedex, France, ${ }^{4}$ Pontificia Universidad Católica del Ecuador, Facultad de Ciencias Exactas y Naturales, Av. 12 de Octubre y Roca, Quito, Ecuador 
Speelman and García-Barrios 2010, Schreinemachers and Berger 2011, Astier et al. 2012), little attention has been paid to agricultural pest management (Carrasco et al. 2010, 2012, Rebaudo and Dangles 2011, 2013).

Here, we assessed the impacts of climatic and economic variability on farmers' adaptive management in agricultural pest control in the Ecuadorian Andes. As a study model, we used the potato tuber moth Tecia solanivora, an invasive species from Guatemala that was introduced to South America via infested potato seeds that were likely imported from Costa Rica in the late 1990s (TorresLeguizamón et al.2011). Because of its economic importance and its ability to successfully invade new production areas of the Ecuadorian Andes, T. solanivora represents one of the major pest problems in the region (Dangles et al. 2009, Crespo-Pérez et al. 2011).

T. solanivora is an excellent candidate to develop an ABM of AM in pest control for two main reasons: (1) its population dynamics have already been documented and implemented into spatiallyexplicit landscape models (Crespo-Pérez et al. 2011) and (2) the decision-making processes that farmers are using to control it have been studied in detail (Dangles et al. 2010, Paredes 2010, Rebaudo and Dangles 2011).

The main objective of our study was to examine how climatic and economic variability, represented as fluctuations in temperature and crop price around a steady mean, affected pest management practices of individual farmers and subsequent pest control strategies at the community level. We developed an ABM to simulate an artificial society of farmers in an Ecuadorian agroecosystem, parameterized with field data. We then used this model to explore farmers' use of AM, i.e., their capacity to adapt their pest management practices under uncertainty, through different scenarios of climatic and economic variability. We were particularly interested in exploring AM at the community level, as a collective measure of AM by individual farmers. We conclude with a discussion of our findings and highlight implications for adaptive management in pest control.

\section{METHODS}

Our simulations were performed using an ABM that allowed us to represent (1) a heterogeneous agricultural landscape, (2) crop pest population dynamics, and (3) humans managing their crops (Filatova et al. 2013). This social-ecological system was subject to both climatic and economic variability, represented as fluctuations in temperature and crop price around a steady mean. The variability fed into farmers' pest management practices, which could lead them to improve their crop production. Farmers responded to pest damages with different behaviors based on their perceptions, experiences, and their personal representation of the system (mental model, see Jones et al. 2011). A representation of the model structure is provided in Figure 1, including the landscape, pest, human, and economic submodels.

The overall model initializes with the landscape submodel, on which farmers are located together with the crop pests. Each time step in the model includes the following processes: (1) economic and climatic variability, (2) pest reproduction, (3) farmers' success at controlling pests (pest control) and adaptive management, (4) pest dispersion. The source code and the documentation of the model-following the ODD protocol (Grimm et al. 2010) and the ODD+D protocol (Müller et al. 2013) are available on the openabm.org platform (https://www.openabm.org/model/4128/, model MANPEST). The model was implemented using the multiagent programmable modeling environment NetLogo version 5.1.0 (Wilensky 1999). Analyses were performed using R software (R Core Team 2014).

\section{The landscape submodel}

We developed a spatially explicit representation of land use in an Andean agricultural landscape in Ecuador (Crespo-Pérez et al. 2011). The agricultural landscape was divided into farm households with an average area of $1.6 \pm 1$ ha, in the range of farm households observed in the Ecuadorian Andes (Nguema et al. 2013). The overall landscape area covered 1000 ha ( $2000 \times 5000$ $\mathrm{m}$, which corresponds to around 600 farms), and was represented as a matrix of 4000 cells (50-m resolution) using a Voronoï tessellation (O'Sullivan and Perry 2013). We represented temperature using two scenarios. The first scenario, referred to as the scenario without temperature variability, relied on temperatures in the Ecuadorian Andes for periods of six months (one time step in the model), corresponding to 15 degrees at around $2500 \mathrm{~m}$. At this temporal scale we observed little variation in temperatures (less than one degree), as reported by Dangles et al. (2008, Appendix A). The second scenario, referred to as the scenario with temperature variability, was built to obtain temperatures outside the range of pest survival (Crespo-Pérez et al. 2011), by randomly choosing a temperature in a Gaussian distribution centered at 15 degrees and with a standard deviation of 5, for each time step in the model. The landscape was considered thermally homogeneous in space and fluctuating in time.

\section{The pest submodel}

Our pest submodel simulated the population dynamics of the potato tuber moth Tecia solanivora (Dangles et al. 2009, CrespoPérez et al. 2011). Its development is mainly driven by temperature. The relationship between $T$. solanivora survival and temperature can be fitted by a Sharpe and DeMichele model (Dangles et al. 2008 and Fig. A1.1).

The population dynamics of $T$. solanivora was modeled through a physiologically-based model detailed in Crespo-Pérez et al. 2011. Briefly, the $T$. solanivora model simulates the spatiotemporal dynamics of the pest on a spatially explicit landscape. One time step in the model corresponds to one T. solanivora generation, or approximately six months. This model has been validated using four years of field data (Crespo-Pérez et al. 2011).

The $T$. solanivora model was modified in this study to fit a change in landscape scale by adapting dispersion to the landscape resolution. The effect of landscape resolution on pest dynamics was verified by comparing the mean dispersal distances at different resolutions, ensuring that we reproduced the population dynamics and spatial distribution. No significant differences were observed between the original model and the adapted model (Student's t-test between the mean dispersal distances: $T$ $=-1.4567, d f=89.435, p$-value $=0.1487)$.

\section{Economic submodel (potato price variability)}

The economic submodel represents the variation in potato prices, used as a proxy for farm revenue in the human submodel (Fig. 1). It considers the monthly potato price between 1990 and 2005 (data from SIGAGRO, Coordinación Consejo Consultivo Papa). These data revealed an increase in prices from 1990 to 2005 (linear regression, $F=18.6, d f=1 / 190, p$-value $<0.05)$. Because we were 
Fig. 1. Representation of the model structure (nonformal graphics). The underlying model is composed of a network of interacting farmers who are capable of learning and adapting to circumstances. They work on farms that are facing the impact of an agricultural pest that evolves. The model includes (1) a landscape submodel, which represents the landscape characteristics and climatic condition, (2) an economic submodel that generates the potato price, (3) a pest submodel, which simulates the pest population dynamics, and (4) a human submodel, which represents farmers who are dealing with the pest and using adaptive management. The grey boxes represent input and output variables and grey stars the analyzed input variables (temperature variability and potato price fluctuation).

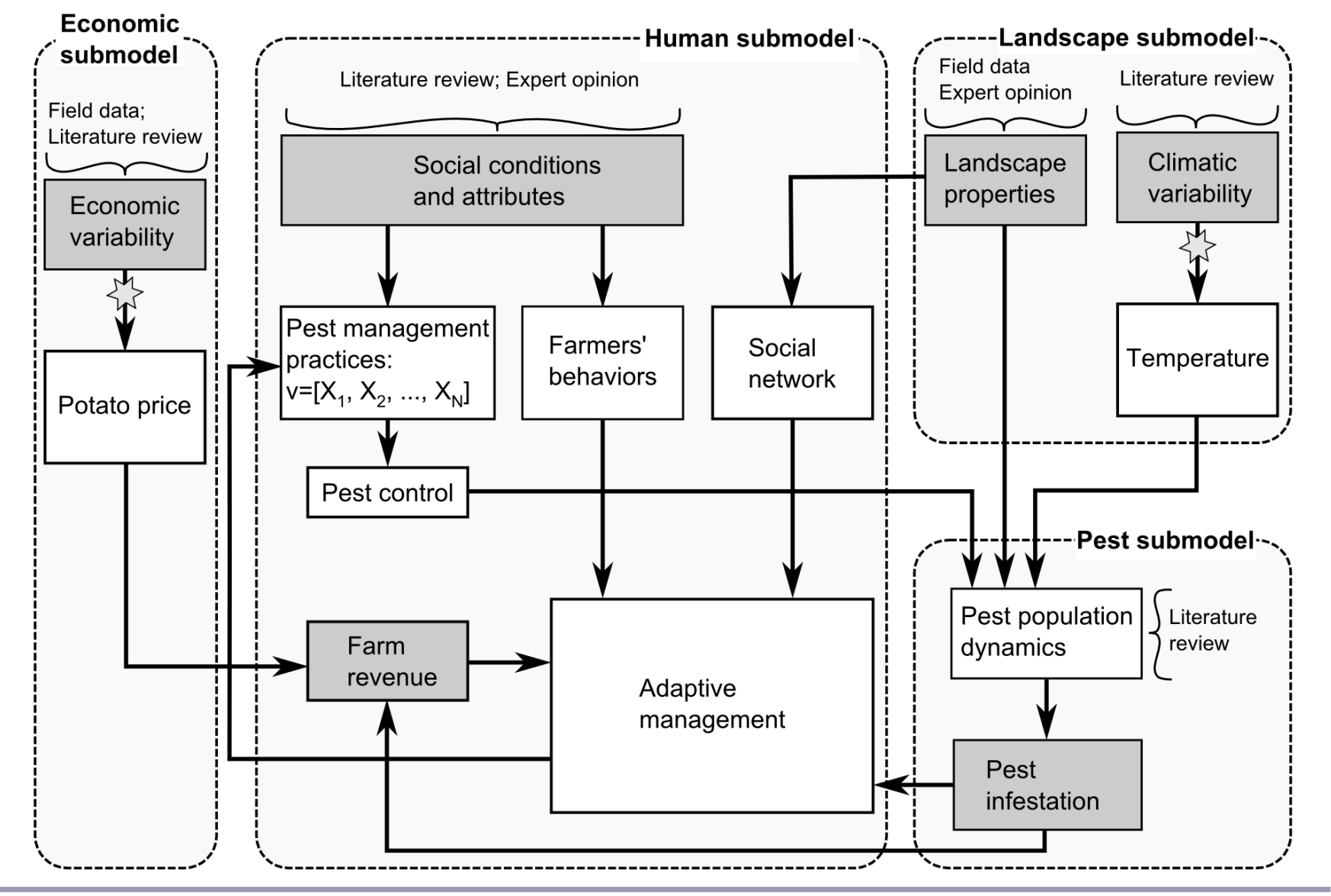

interested in testing the effect of economic variability (random component of potato price time series, see Fig. A1.2), we used an additive model to fit the data (Cowpertwait and Metcalfe 2009). By normalizing and decomposing the time series biannually to subtract the trend, we obtained the expected variation in potato price over time. The potato price standard deviation was 26.7 for a mean value of $100\left(\mathrm{CI}_{95 \%}=[89.7 ; 109.6]\right)$, with a Gaussian-like distribution (Shapiro-Wilk normality test over the random component of the potato price: $W=0.96$; $p$-value $=0.38)$. We used this distribution to simulate economic variability. We assumed that potato prices had no influence on whether farmers decided to plant potatoes, i.e., the same areas were cultivated each year.

\section{The human submodel}

Farmers' pest management practices and their success at pest control

We represented an artificial society of Ecuadorian famers (potato growers) who had to face an invasive agricultural pest for which optimal pest management practices were virtually unknown.
Farmers were initialized individually with a set of pest management practices, which determined their ability to control the pest. The pest management practices were set to reproduce observed pest control in the Ecuadorian Andes. This human submodel interacted with the pest submodel, as pest population dynamics depended on both human pest management strategies and on temperature.

In our simulations, farmers were set with limited cognitive resources (Jager et al. 2000). They could not distinguish between outcomes attributable to pest management practices and those attributable to climatic variability. When farmers' revenue or pest infestation levels were no longer satisfactory, they adapted their pest management practices based on information from other farmers or on their own past experience.

As previously shown by Rebaudo and Dangles (2011), the specific management practices used by Ecuadorian farmers influences how well $T$. solanivora is controlled. For example, high potato ridging more effectively controls potato moth larvae than does low ridging. This example suggests that, to a certain extent, the 
Table 1. Characteristics of behaviors followed by Ecuadorian farmers.

\begin{tabular}{|c|c|c|c|c|c|}
\hline Farmers' behaviors & Conventional & Averse to risk & Experimenters & Risk takers & Averse to change \\
\hline Short description & $\begin{array}{l}\text { Strategically mix } \\
\text { tradition with modern } \\
\text { practices, base } \\
\text { decisions on crop } \\
\text { monitoring }\end{array}$ & $\begin{array}{l}\text { Use effective } \\
\text { techniques, } \\
\text { independent from } \\
\text { markets }\end{array}$ & $\begin{array}{l}\text { Adapt through } \\
\text { experimentation }\end{array}$ & $\begin{array}{l}\text { Take risks and } \\
\text { recommendations from } \\
\text { technicians in commercial } \\
\text { shops }\end{array}$ & $\begin{array}{l}\text { Averse to modifying } \\
\text { their practices }\end{array}$ \\
\hline $\begin{array}{l}\text { Adaptive } \\
\text { management } \\
\text { behavior }\end{array}$ & $\begin{array}{l}\text { Based on observation; } \\
\text { consider own farm } \\
\text { income in past years } \\
\text { and that of other } \\
\text { farmers }\end{array}$ & $\begin{array}{l}\text { Based on validated } \\
\text { techniques; consider } \\
\text { own pest infestation in } \\
\text { past years and that of } \\
\text { other farmers }\end{array}$ & $\begin{array}{l}\text { Based on } \\
\text { experimentation; } \\
\text { consider own farm pest } \\
\text { infestation in past years }\end{array}$ & $\begin{array}{l}\text { Based on external } \\
\text { recommendations } \\
\text { (represented in the model } \\
\text { as experimentation); } \\
\text { consider farm income }\end{array}$ & $\begin{array}{l}\text { No adaptive } \\
\text { management }\end{array}$ \\
\hline $\begin{array}{l}\text { Adaptation } \\
\text { (intensity of } \\
\text { changes) }\end{array}$ & High investment & Low investment & Low investment & High investment & No investment \\
\hline
\end{tabular}

effectiveness of pest management practices can be quantitatively assessed. In our model, we quantitatively represented the set of pest management practices as a vector of dimension $N$. Pest management practices were mostly prophylactic measures, such as cleaning store rooms, ridging potatoes, performing longer crop rotation, but also curative measures such as using pesticides appropriately (Dangles et al. 2010). Each pest management practice $n_{i}$ corresponds to a value that can be compared to a theoretical optimum $n_{0}$, which is the maximum mortality of the pest under a specific pest management practice.

Equation 1 represents the mean distance between a farmer pest management practice and the optimal pest management practice, $\Delta_{\text {practices }}$.

$$
\Delta_{\text {practices }}=\frac{\sum_{i=1}^{N}\left|n_{i}-n_{o}\right|}{N}
$$

$N$ is the dimension of the vector of pest management practices, $n_{i}$ each pest management practice within $N\left(n_{i}\right.$ ranging from 0 to 100 ), and $n_{0}$ the optimal pest management practice.

$$
\text { pest control }=0.15 * \frac{\left(100-\Delta_{\text {practices }}\right)}{20}+0.21
$$

Equation 2 describes how effectively farmers control $T$. solanivora (see Rebaudo and Dangles 2011). Pest control is specific to individual farms. Farmers were randomly assigned pest management strategies based on the known distribution of strategies used in Ecuador. These strategies were saved at each time step in the simulation.

\section{Farmers' behavior}

Faced with emerging threats and associated uncertainties, farmers' pest management practices evolve as a self-organizing process referred to here as AM (sensu Shea et al. 2002). In the model, we represented AM as the farmers' ability to change their pest management practices. The modalities of change in pest management practices varied according to farmers' behaviors, which were fixed for each individual farmer.

In Northern Ecuador, Paredes (2010) elaborated a typology of farmers based on their model of production, how they evaluate success, and how they make decisions. We identified five types of farmers: conventional, experimenters, averse to risk, risk takers, and averse to change. All behaviors coexist in a community of farmers, but one behavior was always described as dominant. See Table 1 for a comparison of the farmers' behaviors.

Two key features distinguish the different types of farmers: (1) what information they use to make pest management decisions and (2) how they evaluate whether their pest management practices have been successful. The information that farmers use to decide whether and how to change their pest management practices can come either from observing other farmers or from evaluating their own past success. Conventional and averse-torisk farmers base their pest management decisions on their perception of others farmers' individual success. They will first assess whose example to follow, then will change pest management practices based on their observations. In contrast, experimenters and risk takers base their pest management decisions on their own individual success. They first assess the success of their past practices, and compare that to the success of current practices. They keep the practices they perceive to be the most effective to try during the next crop cycle.

Many farmers, in our case, experimenters and averse-to-risk farmers, estimate the effectiveness of pest control measures indirectly. They can use surrogates such as the abundance of pests in the field (Railsback and Johnson 2011) or the amount of pest damage (Karp et al. 2013). They are described in the typology as "independent from market." Other farmers, in our case, conventional farmers and risk takers, can estimate the effectiveness of pest control using the economic return from their crop (Below et al. 2012). Note that averse-to-change farmers do not adapt their pest management practices, so do not need criteria for deciding when to change or to evaluate success. 


\section{Farmers' perception and willingness to change}

In our model, farmers were able to perceive pest infestation levels in their own fields and in their neighbors' fields (see Fig. 2). They evaluated pest infestation level in neighboring farms while sharecropping or during labor exchange arrangements, common practices in the Ecuadorian Andes (Paredes 2010). Farmers assessed farm revenue when they sold their crops at marketplaces, so that farm revenue depended on overall production.

Fig. 2. Representation of adaptive management in pest control. Farmers are located on farms that are linked to one another through a social network made up of all neighboring farms. The processes for adaptive management take into account a farmers assessment of his or her own pest infestation and/or farm revenue; a comparison with his or her personal or peers' past success at controlling pests; and the modification of pest management practices.

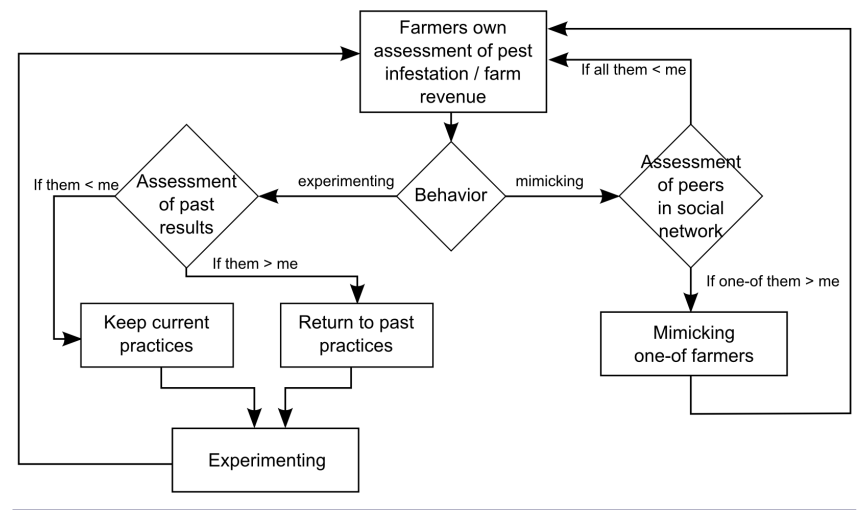

Based on field surveys performed in Ecuador by our team (O. Dangles and F. Rebaudo, unpublished manuscript) we assumed that each farmer could evaluate these two variables and pest management practices over the previous two years. AM (referring here to a modification in pest management practices), was therefore a response to some combination of interactions among farmers, perceptions about their own and other farmers success, observations of pest infestations in the field, and economic returns.

\section{Model validation, simulations, and analyses}

Our human submodel relied on qualitative descriptions based on personal observations and a literature survey. To calibrate farmer behaviors considering the whole model and all its submodels, we optimized the intensity of changes in pest management practice to reproduce the patterns quantified by Paredes (2010). Experimenters and risk takers had higher fluctuations in their revenue compared to averse-to-risk and conventional farmers. This optimization ensured that the selected behaviors produced realistic outputs (e.g., Fig. A1.3). We also checked that, within the range of possible values for the intensity of change, the spread of pest management practices was consistent with studies of how agricultural information spreads (e.g., Bass model in Rebaudo and Dangles 2011).

Farmers' adaptive management was defined as the set of modifications in pest management practices that allowed farmers to limit pest infestation and improve their farm revenue in a context of economic and climatic (temperature) variability. We used model simulations to evaluate the possible impacts of temperature and economic variability on farmers' pest control. We simulated around 600 farmers per simulation with 30 repetitions, $N=5$ pest management practices ranging from $n_{i}=$ 0 to 100 (no difference in model results when $N>5$ ), compared to a theoretical optimum $n_{0}=50$. First, we computed farmers' pest control over 50 years (i.e., 100 time steps using mean pest control of all farmers with 30 simulation repetitions).

We described the resulting curves and analyzed effects of temperature and economic variability through an analysis of variance of farmers' pest control after 50 years (i.e., pest control $\sim$ temperature variability $*$ economic variability). We performed this analysis for the whole community of farmers and for all sets of farmer behaviors. The diversity of pest management practices was represented by the standard deviation. Standard deviations were compared for all sets of farmer behaviors after 50 years using Student's t-tests.

\section{RESULTS}

\section{Impact of climatic and economic variability on farmers' pest control}

Simulations revealed that farmers improve their pest control over time in all scenarios (Fig. 3). However, we found that this improvement was much less when temperature was variable (analysis of variance on farmers' pest control after 50 years, $F=$ $3189, d f=1 / 9532, p$-value $<0.05$; corresponding to $10 \%$ fewer pests). In contrast, economic variability had no significant impact on farmers' pest control over time (analysis of variance on farmers' pest control after 50 years, $F=0.4, d f=1 / 4764, p$-value $=0.52$ ). Because the scenario that included economic variability showed no effect on pest control when compared to the scenario without economic variability, we focused on the effect of temperature variability.

We assessed how different farmers' behaviors affected how their community used adaptive management in response to temperature variability. For all farmers, pest control was significantly different after 25 and 50 years (significant Student's pairwise t-tests between farmers' behaviors with and without temperature variability). The effect of temperature variability on pest control varied with the farmers' behavior. The averse-to-risk farmers controlled pests most successfully under constant conditions, but not when temperature variability was included in the model (Fig. 3A and 3B), where conventional farmers controlled pests most successfully. This was also true for communities dominated by experimenters and risk takers-their pest control strategies were less effective than those of conventional farmers when temperature variability was included in the model.

\section{Impact of climatic variability on the diversity of pest management practices}

We assessed how the heterogeneity in pest management practices in the community was affected by temperature variability. Multiple repetitions (30) of the same simulation without economic or temperature variability revealed that all farmer pest control strategies were similarly effective after 50 years $(C V=$ $0.02)$. We observed a higher coefficient of variation $(C V=0.08)$ when including temperature variability in the model (Fig. 3). 
Fig. 3. Adaptive management in pest control. Farmers' pest control resulting from pest management practices is represented as a function of time without temperature variability (A), and with temperature variability (B). In the left graphs, the different curves represent communities of farmers dominated by conventional farmers (solid black lines), experimenters (dashed black lines), averse-to-risk farmers (solid grey lines), and risk takers (dashed grey lines). Areas shaded in grey represent standard deviations for each curve (30 simulations repetitions). The right graphs represent boxplots of the distribution of farmers' pest control after 50 years.

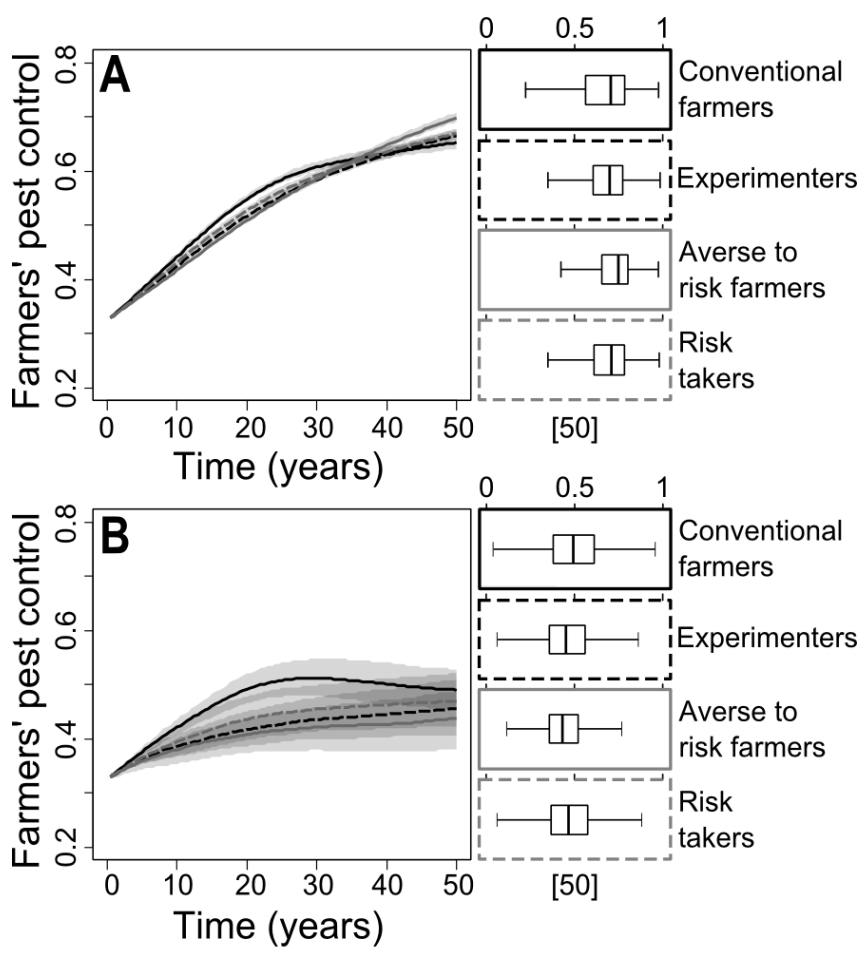

The standard deviation in pest management practices after 50 years was significantly higher in simulations that included temperature variability (Student's t-test, $t=-20.5, d f=36.8, p$ value $<0.05$ ). It stabilized after 25 years (see Fig. 4). Farmers with different pest management practices coexist and are maintained over time.

Heterogeneity in pest management practices decreased over 50 years when the model did not include temperature variability, leading to homogenization of pest management practices. This result applied to all communities, no matter the dominant farmers' behavior.

\section{DISCUSSION}

Our modeling approach is based on a strong empirical background of both pest population dynamics and farmers' pest management behavior. This approach remains exploratory, and must be applied to the real world with caution (Grüne-Yanoff 2009). However, we think our approach proposes a novel methodology to explore and predict the consequences of climatic and economic uncertainty on farmers' use of adaptive management in pest control.
Fig. 4. Evolution of heterogeneity in farmers' pest management practices. The standard deviation in pest management practices for all farmers in a simulation was used to represent heterogeneity. Standard deviations were represented using boxplots (30 repetitions) without temperature variability in white, and with temperature variability in grey. After 25 years with temperature variability, heterogeneity in pest management practices stabilized. In contrast, it continued to decrease when there was no temperature variability, leading to homogenization of pest management practices.

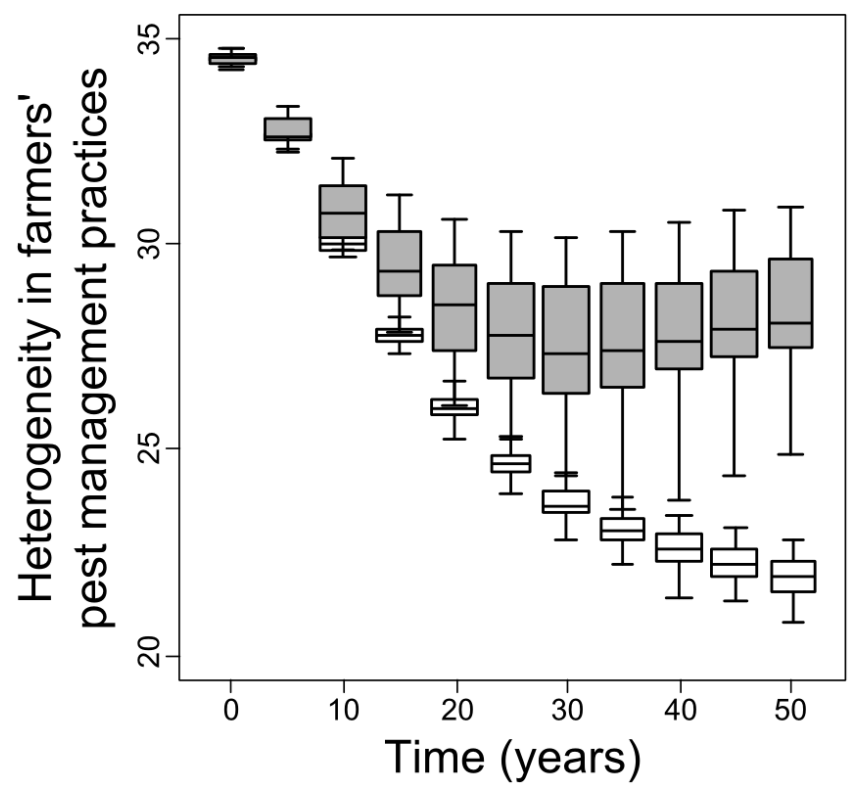

\section{Impacts of climatic and economic variability on farmers' pest control}

Our study revealed that efforts to deal with common problems such as agricultural pests would be less effective in a context of climatic variability. Uncertainty is common in biological systems and central to the concept of adaptive management (Rist et al. 2013). In our model, adaptive management emerged from socialecological interactions within the agro-ecosystem in a process that includes coping with uncertainties. Our modeling approach supports the idea that adaptive management would be effective when there is a lot of uncertainty, but it would take more time to reach the same level of control than in a situation without variability.

In their study on Bali water temples, Lansing and Miller (2005) suggest that community-level responses can emerge from common problems such as pest management. In this sense, intervention programs such as farmer field schools (Van den Berg and Jiggins 2007) or collaborative monitoring (FernandezGimenez et al. 2008, Dangles et al. 2010) may foster adaptive management and community-level responses by increasing farmers' knowledge of pest ecology in relation to climatic variability, therefore reducing uncertainties related to the pest dynamics.

Additionally, our model demonstrated that climatic variability, represented in our model as temperature, produced heterogeneity 
in farmers' pest control strategies. This suggests that variability itself influenced pest control strategies, which may also be the case with different temperature time series. In that sense, farmers' pest control can be considered path-dependent, because local rules of interaction between the farmers and the pest evolve as a result of the balance between human-dependent and temperature-dependent pest survival (Folke 2006). It means that a particular series of climatic events can lead to large deviations from the average pest control strategy.

In the specific case of tropical Andean small-hold farmers, the strong altitudinal gradients and land-use heterogeneity (Dangles et al. 2008) resulted in different situations even at a small scale, thereby increasing path-dependency. This characteristic of adaptive systems has been documented in land-use models (e.g., Brown et al. 2005, Celio et al. 2014), and has negative consequences on the predictability of an adaptive system.

Our findings revealed that economic variability (variation in potato price) did not influence farmers' pest control strategies. This is surprising, because interviews with farmers in the field often indicated that potato price variability is an important driver of potato grower behavior (Dangles et al. 2010). This could be because we assumed that the area in cultivated in potatoes was constant. However, many Andean subsistence-oriented potato growers do claim to be market independent (Paredes 2010) and rely on several agricultural activities to strengthen their food security and economic stability.

\section{Community adaptive management to economic and climatic variability}

\section{Farmers' behaviors}

Our model was calibrated using farmers' behaviors described in the literature (Paredes 2010), and did not attempt to define the most effective behavior in the face of climatic or economic variability. However, our study is pertinent to exploring how different farmers' behaviors respond to environmental variability. Conventional and averse-to-risk farmers both mimic the behaviors of others, and as such are quite similar in terms of underlying mechanisms. However, the shape of the pest control curves for farmers with these two behaviors differed from one another (Fig. 3).

In their paper on adaptive management, Rist et al. (2013) discussed when adaptive management is appropriate, highlighting that "ecological uncertainty must be a key obstacle for management." Our theoretical study suggests that when there is potential for a great deal of progress in controlling pests, reducing uncertainty is not a key obstacle. This favors communities dominated by conventional farmers over averse-to-risk farmers in the early years of our simulations.

\section{Heterogeneity in pest management practices}

Our study highlights that uncertainty may play a key role in orienting and maintaining heterogeneous pest management practices, and supports the idea that farmers' personal representation of the system (mental model) is a key determinant of adaptive management (Grothmann and Patt 2005, AcostaMichlik and Espaldon 2008). Here we assumed that farmers' perceptions of how effective their pest management strategies were depend on the level of pest infestation in their field, and not the true efficiency of the strategy. A farmer mimicking another farmer changed practices based on his/her perception of how effectively pests were controlled (Fig. 2).

In the simulations that included climatic variability, the level of pest infestation was the result of how effective the pest control strategy was, and of temperature-dependent pest mortality. Farmers faced more uncertainty about the most efficient pest management practices, because they could not distinguish between these two influences on infestation, leading them to adopt to nonoptimal pest management practices. Consequently, we observed more diversity in pest management practices at the community level when temperature was variable. At a broader scale, our theoretical results suggest that uncertainty may be crucial for maintaining diversity in pest management practices. Theoretically, this uncertainty-driven diversity should strengthen the adaptive management of the social-ecological systems at the community level, (Olsson et al. 2004, Lin 2011, Barthel et al. 2013).

\section{Adaptive management of a common problem}

In their paper about competitiveness in traditional fishing societies, Leibbrandt et al. (2013) found that individuals tend to be less competitive and favor teamwork in collectivistic societies, where nature constrains humans to work together. Our study highlights how people must depend on one another when facing a common problem (control of crop pest). This could be regarded as a "coevolutionary relationship": When they adapt their practices in response to a constraint by imitating successful behavior, humans "coevolve" with each other to maximize their benefits (here farmers in rural Ecuadorian Andes face the need to improve pest control; Mitleton-Kelly and Davy 2013). In our model, this coevolution through imitation and experimentation is taking the form of adaptive management. At a broader scale, it supports the idea that adaptive management may be the result of exposure to a common problem, even if some individual farmers-depending on their social environment (neighboring farmers) and/or physical environment (climate variability) may benefit less from adaptive management.

\section{CONCLUSION}

In conclusion, our simulation approach consisted of a modeling framework that considered both spatial and temporal dynamics, where social and ecological systems constantly interact with each other. In this system, adaptive management in pest control emerged when farmers were represented as heterogeneous agents who interacted and influenced each other, and who were capable of learning and adapting to circumstances. The results of our study stress the importance of farmers' perceptions and uncertainties in their decision-making processes that result in adaptive management. It also highlighted the possible role of uncertainty in maintaining diversity in pest management practices, which helps make farmers more resilient. At a broader scale, it will help improve understanding of the mechanisms that drive a shift to adaptive management. Grounded on field data, a validated pest model, and consistent with described studies, this study provides a valuable framework to study social-ecological responses to global changes.

Responses to this article can be read online at: http://www.ecologyandsociety.org/issues/responses. $\mathrm{php} / 7511$ 


\section{Acknowledgments:}

This work was conducted within the project "Adaptive management in insect pest control in thermally heterogeneous agricultural landscapes" (ANR-12-JSV7-0013-01) funded by the Agence Nationale pour la Recherche (ANR).

\section{LITERATURE CITED}

Acosta-Michlik, L., and V. Espaldon. 2008. Assessing vulnerability of selected farming communities in the Philippines based on a behavioural model of agent's adaptation to global environmental change. Global Environmental Change 18:554-563. http://dx.doi.org/10.1016/j.gloenvcha.2008.08.006

An, L. 2012. Modeling human decisions in coupled human and natural systems: review of agent-based models. Ecological Modelling 229:25-36. http://dx.doi.org/10.1016/j.ecolmodel.2011.07.010

Astier, M., L. García-Barrios, Y. Galván-Miyoshi, C. E. González-Esquivel, and O. R. Masera. 2012. Assessing the sustainability of small farmer natural resource management systems. A critical analysis of the MESMIS Program (1995-2010). Ecology and Society 17(3): 25. http://dx.doi.org/10.5751/ ES-04910-170325

Barthel, S., C. Crumley, and U. Svedin. 2013. Bio-cultural refugia - safeguarding diversity of practices for food security and biodiversity. Global Environmental Change 23:1142-1152. http:// dx.doi.org/10.1016/j.gloenvcha.2013.05.001

Below, T. B., K. D. Mutabazi, D. Kirschke, C. Franke, S. Sieber, R. Siebert, and K. Tscherning. 2012. Can farmers' adaptation to climate change be explained by socio-economic household-level variables? Global Environmental Change 22:223-235. http://dx. doi.org/10.1016/j.gloenvcha.2011.11.012

Berger, T. 2001. Agent-based spatial models applied to agriculture: a simulation tool for technology diffusion, resource use changes and policy analysis. Agricultural Economics 25:245-260. http://dx.doi.org/10.1111/j.1574-0862.2001.tb00205. $\underline{\mathrm{X}}$

Boone, R. B., K. A. Galvin, S. B. BurnSilver, P. K. Thornton, D. S. Ojima, and J. R. Jawson. 2011. Using coupled simulation models to link pastoral decision making and ecosystem services. Ecology and Society 16(2): 6. [online] URL: http://www. ecologyandsociety.org/vol16/iss2/art6/

Brown, D. G., S. Page, R. Riolo, M. Zellner, and W. Rand. 2005. Path dependence and the validation of agent-based spatial models of land use. International Journal of Geographical Information Science 19:153-174. http://dx.doi.org/10.1080/13658810410001713399

Cabell, J. F., and M. Oelofse. 2012. An indicator framework for assessing agroecosystem resilience. Ecology and Society 17(1): 18. http://dx.doi.org/10.5751/ES-04666-170118

Carrasco, L. R., D. Cook, R. Baker, A. MacLeod, J. D. Knight, and J. D. Mumford. 2012. Towards the integration of spread and economic impacts of biological invasions in a landscape of learning and imitating agents. Ecological Economics 76:95-103. http://dx.doi.org/10.1016/j.ecolecon.2012.02.009

Carrasco, L. R., J. D. Mumford, A. MacLeod, T. Harwood, G. Grabenweger, A. W. Leach, J. D. Knight, and R. H. A. Baker.
2010. Unveiling human-assisted dispersal mechanisms in invasive alien insects: integration of spatial stochastic simulation and phenology models. Ecological Modelling 221:2068-2075. http:// dx.doi.org/10.1016/j.ecolmodel.2010.05.012

Celio, E., T. Koellner, and A. Grêt-Regamey. 2014. Modeling land use decisions with Bayesian networks: spatially explicit analysis of driving forces on land use change. Environmental Modelling \& Software 52:222-233. http://dx.doi.org/10.1016/j.envsoft.2013.10.014

Cowpertwait, P. S. P., and A. V. Metcalfe. 2009. Introductory time series with $R$. Springer, Dordrecht, The Netherlands.

Crespo-Pérez, V., F. Rebaudo, J.-F. Silvain, and O. Dangles. 2011. Modeling invasive species spread in complex landscapes: the case of potato moth in Ecuador. Landscape Ecology 26:1447-1461. http://dx.doi.org/10.1007/s10980-011-9649-4

Dangles, O., C. Carpio, A. R. Barragan, J.-L. Zeddam, and J.-F. Silvain. 2008. Temperature as a key driver of ecological sorting among invasive pest species in the tropical Andes. Ecological Applications 18:1795-1809. http://dx.doi.org/10.1890/07-1638.1

Dangles, O., F. C. Carpio, M. Villares, F. Yumisaca, B. Liger, F. Rebaudo, and J. Silvain. 2010. Community-based participatory research helps farmers and scientists to manage invasive pests in the Ecuadorian Andes. AMBIO: A Journal of the Human Environment 39:325-335. http://dx.doi.org/10.1007/s13280-010-0041-4

Dangles, O., V. Mesías, V. Crespo-Perez, and J.-F. Silvain. 2009. Crop damage increases with pest species diversity: evidence from potato tuber moths in the tropical Andes. Journal of Applied Ecology 46:1115-1121. http://dx.doi.org/10.1111/j.1365-2664.2009.01703. $\underline{x}$

Darnhoffer, I., S. Bellon, B. Dedieu, and R. Milestad. 2010. Adaptiveness to enhance the sustainability of farming systems: a review. Agronomy for Sustainable Development 30(3):545-555. http://dx.doi.org/10.1051/agro/2009053

Fernandez-Gimenez, M. E., H. L. Ballard, and V. E. Sturtevant. 2008. Adaptive management and social learning in collaborative and community-based monitoring: a study of five communitybased forestry organizations in the western USA. Ecology and Society 13(2): 4. [online] URL: http://www.ecologyandsociety. org/vol13/iss2/art4/

Filatova, T., P. H. Verburg, D. C. Parker, and C. A. Stannard. 2013. Spatial agent-based models for socio-ecological systems: challenges and prospects. Environmental Modelling \& Software 45:1-7. http://dx.doi.org/10.1016/j.envsoft.2013.03.017

Folke, C. 2006. Resilience: the emergence of a perspective for social-ecological systems analyses. Global Environmental Change 16:253-267. http://dx.doi.org/10.1016/j.gloenvcha.2006.04.002

Grimm, V., U. Berger, D. L. DeAngelis, J. G. Polhill, J. Giske, and S. F. Railsback. 2010. The ODD protocol: a review and first update. Ecological Modelling 221:2760-2768. http://dx.doi. org/10.1016/j.ecolmodel.2010.08.019

Grothmann, T., and A. Patt. 2005. Adaptive capacity and human cognition: the process of individual adaptation to climate change. Global Environmental Change 15:199-213. http://dx.doi. org/10.1016/j.gloenvcha.2005.01.002 
Grüne-Yanoff, T. 2009. The explanatory potential of artificial societies. Synthese 169:539-555. http://dx.doi.org/10.1007/ $\underline{\text { s11229-008-9429-0 }}$

Happe, K., K. Kellermann, and A. Balmann. 2006. Agent-based analysis of agricultural policies: an illustration of the agricultural policy simulator AgriPoliS, its adaptation, and behavior. Ecology and Society 11(1): 49. [online] URL: http://www.ecologyandsociety. org/vol11/iss1/art49/

Holling, C. S. 1978. Adaptive environmental assessment and management. Wiley, Chichester, UK.

Jager, W., M. A. Janssen, H. J. M. De Vries, J. De Greef, and C. A. J. Vlek. 2000. Behaviour in commons dilemmas: Homo economicus and Homo psychologicus in an ecological-economic model. Ecological Economics 35:357-379. http://dx.doi. org/10.1016/S0921-8009(00)00220-2

Jones, N. A., H. Ross, T. Lynam, P. Perez, and A. Leitch. 2011. Mental models: an interdisciplinary synthesis of theory and methods. Ecology and Society 16(1): 46. [online] URL: http:// www.ecologyandsociety.org/vol16/iss1/art46/

Karp, D. S., C. D. Mendenhall, R. F. Sandí, N. Chaumont, P. R. Ehrlich, E. A. Hadly, and G. C. Daily. 2013. Forest bolsters bird abundance, pest control and coffee yield. Ecology Letters 16 (11):1339-1347. http://dx.doi.org/10.1111/ele.12173

Lansing, J. S., and J. H. Miller. 2005. Cooperation, games, and ecological feedback: some insights from Bali. Current Anthropology 46(2):328-333. http://dx.doi.org/10.1086/428790

Leibbrandt, A., U. Gneezy, and J. A. List. 2013. Rise and fall of competitiveness in individualistic and collectivistic societies. Proceedings of the National Academy of Sciences 110:9305-9308. http://dx.doi.org/10.1073/pnas. 1300431110

Lewis, W. J., J. C. van Lenteren, S. C. Phatak, and J. H. Tumlinson. 1997. A total system approach to sustainable pest management. Proceedings of the National Academy of Science of the USA 94:12243-12248. http://dx.doi.org/10.1073/pnas.94.23.12243

Lin, B. B. 2011. Resilience in agriculture through crop diversification: adaptive management for environmental change. BioScience 61:183-193. http://dx.doi.org/10.1525/bio.2011.61.3.4

Liu, J., T. Dietz, S. R. Carpenter, C. Folke, M. Alberti, C. L. Redman, S. H. Schneider, E. Ostrom, A. N. Pell, J. Lubchenco, W. W. Taylor, Z. Ouyang, P. Deadman, T. Kratz, and W. Provencher. 2007. Coupled human and natural systems. AMBIO: A Journal of the Human Environment 36:639-649. http://dx.doi. org/10.1579/0044-7447(2007)36[639:CHANS]2.0.CO;2

Matthews, R. B., N. G. Gilbert, A. Roach, J. G. Polhill, and N. M. Gotts. 2007. Agent-based land-use models: a review of applications. Landscape Ecology 22:1447-1459. http://dx.doi. org/10.1007/s10980-007-9135-1

Millennium Ecosystem Assessment (MEA). 2005. Ecosystems and human well-being: synthesis. Island Press, Washington, D.C., USA.

Mitleton-Kelly, E., and L. K. Davy. 2013. The concept of 'coevolution' and its application in the social sciences: a review of the literature. Pages 43-57 in E. Mitleton-Kelly, editor. Co- evolution of intelligent socio-technical systems. Springer Berlin Heidelberg, Germany. http://dx.doi.org/10.1007/978-3-642-36614-7_3

Müller, B., F. Bohn, G. Dreßler, J. Groeneveld, C. Klassert, R. Martin, M. Schlüter, J. Schulze, H. Weise, and N. Schwarz. 2013. Describing human decisions in agent-based models - ODD + D, an extension of the ODD protocol. Environmental Modelling \& Software 48:37-48. http://dx.doi.org/10.1016/j.envsoft.2013.06.003

Nguema, A., G. W. Norton, J. Alwang, D. B. Taylor, V. Barrera, and M. Bertelsen. 2013. Farm-level economic impacts of conservation agriculture in Ecuador. Experimental Agriculture 49:134-147. http://dx.doi.org/10.1017/S0014479712001044

Olsson, P., C. Folke, and F. Berkes. 2004. Adaptive comanagement for building resilience in social-ecological systems. Environmental Management 34:75-90. http://dx.doi.org/10.1007/s00267-003-0101-7

O'Sullivan, D., and G. L. W. Perry. 2013. Aggregation and segregation. Pages 57-95 in D. O'Sullivan, and G. L. W. Perry. Spatial simulation: exploring pattern and process. John Wiley \& Sons, Chichester, UK.

Paredes, M. 2010. Peasants, potatoes, and pesticides: heterogeneity in the context of agricultural modernization in the Highland Andes of Ecuador. Wageningen University, Wageningen, The Netherlands.

Parker, D. C., S. M. Manson, M. A. Janssen, M. J. Hoffmann, and P. Deadman. 2003. Multi-agent systems for the simulation of land-use and land-cover change: a review. Annals of the Association of American Geographers 93:314-337. http://dx.doi. org/10.1111/1467-8306.9302004

Parrott, L., C. Chion, R. Gonzalès, and G. Latombe. 2012. Agents, individuals, and networks: modeling methods to inform natural resource management in regional landscapes. Ecology and Society 17(3): 32. http://dx.doi.org/10.5751/ES-04936-170332

Perez, C., C. Nicklin, O. Dangles, S. Vanek, S. G. Sherwood, S. Halloy, K. A. Garrett, and G. A. Forbes. 2010. Climate change in the High Andes: implications and adaptation strategies for small-scale farmers. International Journal of Environmental, Cultural, Economic and Social Sustainability 6:71-88.

R Core Team. 2014. R: A language and environment for statistical computing. R Foundation for Statistical Computing, Vienna, Austria.

Railsback, S. F., and M. D. Johnson. 2011. Pattern-oriented modeling of bird foraging and pest control in coffee farms. Ecological Modelling 222(18):3305-3319. http://dx.doi.org/10.1016/ j.ecolmodel.2011.07.009

Rebaudo, F., and O. Dangles. 2011. Coupled information diffusion-pest dynamics models predict delayed benefits of farmer cooperation in pest management programs. PLoS Computational Biology 7(10):e1002222. http://dx.doi.org/10.1371/ journal.pcbi.1002222

Rebaudo, F., and O. Dangles. 2013. An agent-based modeling framework for integrated pest management dissemination programs. Environmental Modelling \& Software 45:141-149. http://dx.doi.org/10.1016/j.envsoft.2012.06.014 
Rist, L., A. Felton, L. Samuelsson, C. Sandström, and O. Rosvall. 2013. A new paradigm for adaptive management. Ecology and Society 18(4): 63. http://dx.doi.org/10.5751/ES-06183-180463

Rounsevell, M. D. A., D. T. Robinson, and D. Murray-Rust. 2012. From actors to agents in socio-ecological systems models. Philosophical Transactions of the Royal Society B: Biological Sciences 367:259-269. http://dx.doi.org/10.1098/rstb.2011.0187

Schreinemachers, P., and T. Berger. 2011. An agent-based simulation model of human-environment interactions in agricultural systems. Environmental Modelling \& Software 26:845-859. http://dx.doi.org/10.1016/j.envsoft.2011.02.004

Shea, K., H. P. Possingham, W. W. Murdoch, and R. Roush. 2002. Active adaptive management in insect pest and weed control: intervention with a plan for learning. Ecological Applications 12:927-936. http://dx.doi.org/10.1890/1051-0761(2002)012[0927: AAMIIP]2.0.CO;2

Speelman, E. N., and L. E. García-Barrios. 2010. Agrodiversity v.2: an educational simulation tool to address some challenges for sustaining functional agrodiversity in agro-ecosystems. Ecological Modelling 221:911-918. http://dx.doi.org/10.1016/j. ecolmodel.2009.12.007

Susskind, L., A. E. Camacho, and T. Schenk. 2012. A critical assessment of collaborative adaptive management in practice. Journal of Applied Ecology 49:47-51. http://dx.doi.org/10.1111/ j.1365-2664.2011.02070.x

Torres-Leguizamón, M., S. Dupas, D. Dardon, Y. Gómez, L. Niño, A. Carnero, A. Padilla, I. Merlin, A. Fossoud, J.-L. Zeddam, X. Lery, C. Capdevielle-Dulac, O. Dangles, and J.-F. Silvain. 2011. Inferring native range and invasion scenarios with mitochondrial DNA: the case of T. solanivora successive northsouth step-wise introductions across Central and South America. Biological Invasions 13:1505-1519. http://dx.doi.org/10.1007/ s10530-010-9909-2

Van den Berg, H., and J. Jiggins. 2007. Investing in farmers-the impacts of farmer field schools in relation to integrated pest management. World Development 35:663-686. http://dx.doi. org/10.1016/j.worlddev.2006.05.004

Watkins, C., D. Massey, J. Brooks, K. Ross, and M. L. Zellner. 2013. Understanding the mechanisms of collective decision making in ecological restoration: an agent-based model of actors and organizations. Ecology and Society 18(2): 32. http://dx.doi. org/10.5751/ES-05497-180232

Wilensky, U. 1999. NetLogo version 5.1.0. The Center for Connected Learning and Computer-based Modeling, Northwestern University, Evanston, Illinois, USA.

Zellner, M. L. 2008. Embracing complexity and uncertainty: the potential of agent-based modeling for environmental planning and policy. Planning Theory \& Practice 9(4):437-457. http://dx. doi.org/10.1080/14649350802481470 
Fig. A1.1. Pest temperature dependant survival model, following Sharpe and DeMichele (in blue, see Crespo-Pérez et al. 2011 Supplementary material 1 for the model parameters), and temperature variability in our agent-based model (in red). Further sensitivity analyses demonstrated a linear response of farmers' pest control to different degrees of variability in temperature (using a Gaussian distribution centered on 15 degrees and with a standard deviation ranging from 0 to 5 ).

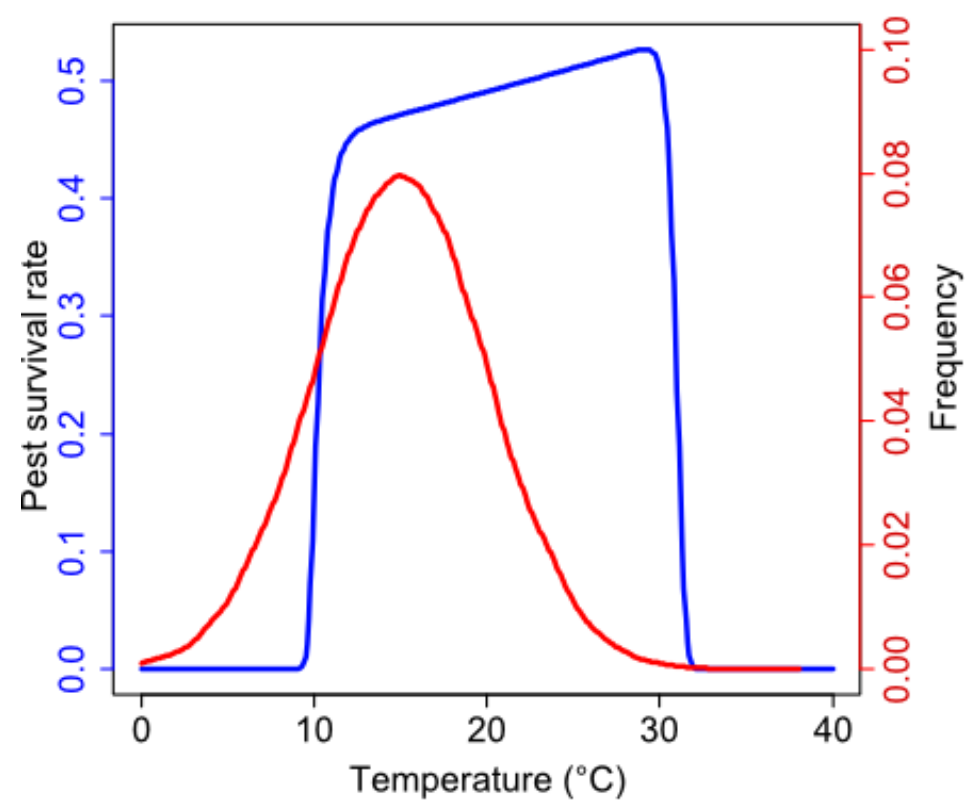




\section{Appendix \#1. Fig. A1.2}

Fig. A1.2. Time series of the potato price in Ecuador observed from 1990 to 2005 (data from SIGAGRO, Coordinación Consejo Consultivo Papa) (A). The time series has been decomposed over periods of 6 months (to fit the temporal scale of the model) according to an additive model (B) to extract the random component of potato price. Then we simulated potato price variability using a normal distribution (C), which has been used to simulate 50 years in our model.

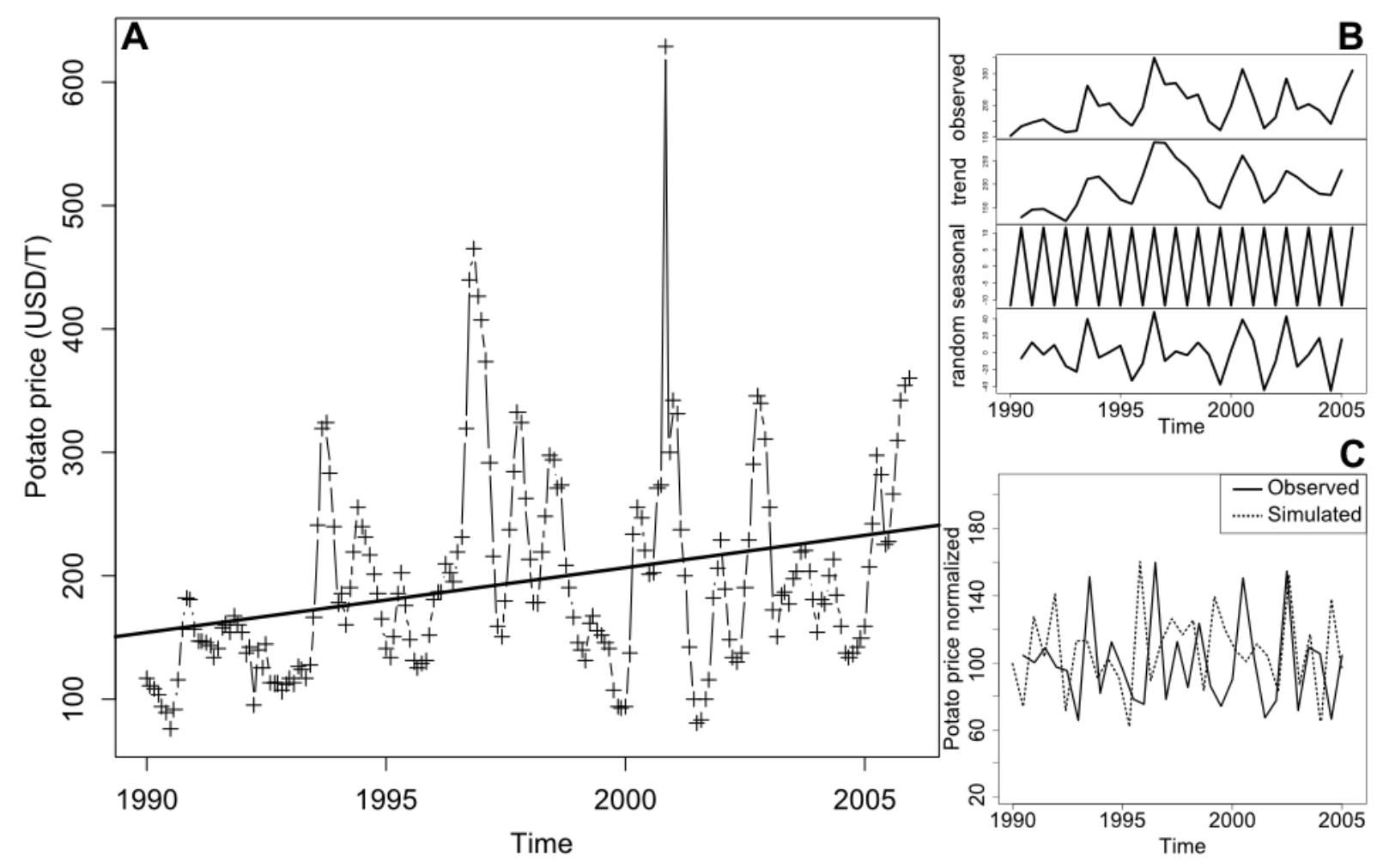




\section{Appendix \#1. Fig. A1.3}

Fig. A1.3. Fluctuations in farm revenue from the optimized model. The standard deviation in farm revenue is represented for the four main farmers' behaviors at equilibrium. As described in the literature, behaviors based on experiments exhibits fluctuations in farm revenue.

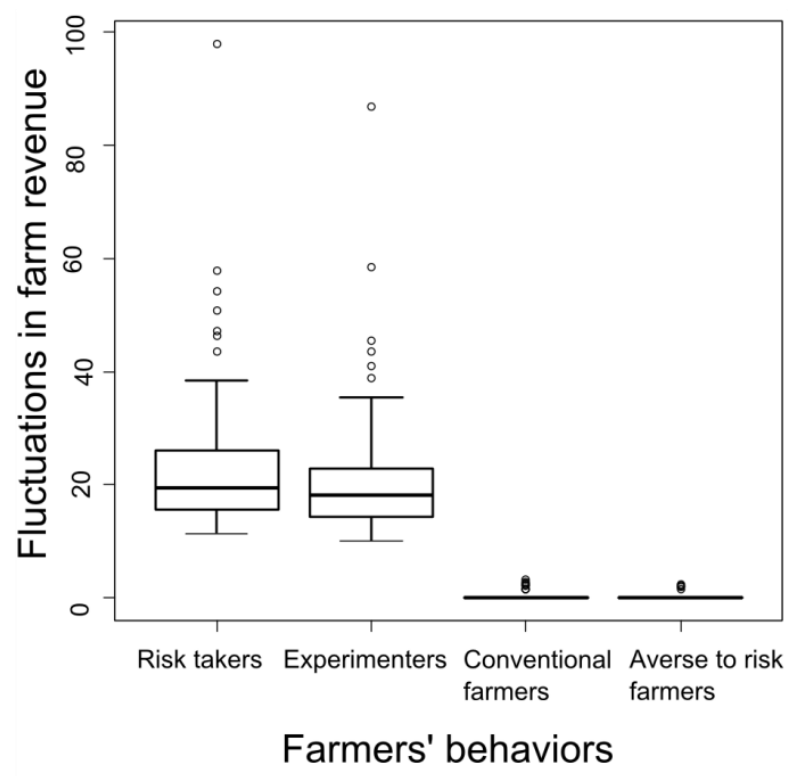

